\title{
Paparan Media Sosial terhadap Perilaku Pemberian ASI Ekslusif di Kota Pontianak
}

\author{
Arina Nurfianti ${ }^{1}$, Murtilita $^{1}$, Siti Rahima ${ }^{2}$ \\ 1 Program Studi Keperawatan Fakultas Kedokteran Universitas Tanjungpura \\ 2 RSU Sultan Syarif Mohammad Alkadrie Pontianak
}

\begin{abstract}
Abstrak
Latar Belakang. Media sosial dianggap sangat efektif dalam mensosialisasikan program kerja pemerintah, maupun menyampaikan informasi yang dapat mengubah persepsi dan perilaku masyarakat. Indonesia saat ini memiliki persentase bayi yang disusui ekslusif sampai 6 bulan hanya 15,3\% sehingga berisiko pada kerawanan status gizi dan imunitas. Metode. Metode penelitian yang digunakan dalam penelitian ini adalah analisis korelasi dengan menggunakan pendekatan cross sectional study pada 35 orang responden di Kota Pontianak. Instrument penelitian telah melalui uji validitas dan reliabilitas yang sahih. Hasil. Analisis data Spearman menunjukkan adanya pengaruh paparan media sosial terhadap perilaku menyusui ASI ekslusif ibu di Kota Pontianak. Kesimpulan. Media sosial mempengaruhi persepsi individu sehingga berdampak pada perilaku menyusui yang efektif oleh ibu kepada bayinya. Paparan informasi dari media sosial sebagai bentuk dukungan tidak langsung kepada ibu berpengaruh pada perilaku ibu dalam memberikan ASI ekslusif.
\end{abstract}

Kata kunci: media sosial, menyusui, ekslusif

Background. Social media is argued quite effective in introduce and explaining government task target in order to gain more perspective vision and changing women behaviour. Indonesia nowdays has only $15.3 \%$ breastfeeding mothers to whom they give exclusive breast milk. Infants are risking in lower nutrition state and immunity. Method. Correlation analysis was used in this research with cross sectional approach to 35 women in Pontianak. Valid and reliable quessionare were used in collecting data. Results. Datas were analised by Spearman rho test. Exposure and explanation of social media to mothers about exclusive breastfeeding show significant correlation to exclusive breastfeeding behaviour in Pontianak. Conclusion. Social media conduct individual perception through the mass information. It has impact on exclusive breastfeeding behaviour among women. Mother breastmilk and exclusive breastfeeding information through social media are part of supports to women having breasfeeding behaviour for their infants.

Key words: social media, breastfeeding, exclusive 
PENDAHULUAN

Data Riset Kesehatan Dasar (Riskesdas) tahun 2010 menunjukkan bahwa pemberian Asi di Indonesia saat ini persentase bayi yang menyusui ekslusif sampai 6 bulan hanya $15,3 \%{ }^{1}$. Data ini cukup memprihatinkan karena terjadinya kerawanan gizi pada bayi disebabkan karena selain makanan yang kurang juga karena Air Susu Ibu (ASI) banyak diganti dengan susu botol dengan cara dan jumlah yang tidak memenuhi kebutuhan. Padahal diperkirakan $80 \%$ dari jumlah ibu yang melahirkan mampu menghasilkan air susu dalam jumlah yang cukup untuk keperluan bayinya secara penuh tanpa makanan tambahan.

Hal ini terjadi karena rendahnya kesadaran masyarakat dalam mendorong peningkatan pemberian asi kepada bayinya. Masalah utama penyebab rendahnya pemberian ASI ekslusive diantaranya faktor sosial budaya, kurangnya pengetahuan ibu - ibu hamil, keluarga dan masyarakat, serta jajaran kesehatan yang belum sepenuhnya mendukung peningkatan pemberian Asi $(\mathrm{PP}-\mathrm{ASI})^{2}$.

$$
\text { Berbagai penelitian pun }
$$
melaporkan, bayi yang diberi susu formula terancam mengalami obesitas dan lebih rentan pada reaksi hipersensitivitas, gangguan pencernaan makanan dan penggunaan protein terhidrolisis ${ }^{3}$. Sebagian pada persentase populasi bayi di dunia dapat megalami reaksi hipersensitivitas pada sistem pencernaan akibat laktosa pada susu formula ${ }^{4}$.

Pemberian susu formula meningkatkan risiko alergi atopic pada anak hingga 24 bulan pertama kelahiran ${ }^{3}$.

United Nation Children's Fund (UNICEF) menyatakan, sebanyak 30.000 kematian bayi di Indonesia dan 10 juta kematian anak balita di dunia setiap tahunnya bisa dicegah melalui pemberian ASI (Air Susu Ibu) secara eksklusif selama enam bulan sejak kelahiran, tanpa harus memberikan makanan atau minuman tambahan pada bayi. UNICEF juga 
menyatakan bahwa bayi yang diberikan susu formula memiliki kemungkinan untuk meninggal dunia pada bulan pertama kelahirannya. Dan peluang itu 25 kali lebih tinggi dibandingkan bayi yang disusui oleh ibunya secara eksklusif 5 .

$$
\text { Berdasarkan keperihatinan }
$$

terhadap rendahnya pengetahuan dan kesadaran masyarakat mengenai pengaplikasian ASI ekslusive dan pemanfaatan kemajuan ilmu pengetahuan dan tekhnologi, maka pemerintah maupun Lembaga Sosial Masyarakat memanfaatkan media social dalam mensosialisasikannya. Semakin mudahnya mengakses media sosial sehingga informasi yang ingin disampaikan kepada masyarakat menjadi lebih mudah ${ }^{6}$. Kampanye mengenai ASI ekslusif pun sering ditemukan baik di radio, televisi, media cetak, maupun internet ${ }^{2}$.

\section{METODE}

Metode penelitian yang digunakan dalam penelitian ini adalah analisis korelasi dengan menggunakan pendekatan cross sectional study. Populasi dalam penelitian ini adalah ibu menyusui di Kota Pontianak. Metode pengumpulan sampel menggunakan metode consecutive sampling (jenis non probability sampling). Metode ini merupakan metode sampel non random yang paling baik jika dibandingkan dengan metode non probability/ non random lainnya ${ }^{7}$. Sampel yang digunakan berjumlah 35 reponden dengan kriteria ibu yang memiliki balita 0 24 bulan. Pengumpulan data dilaksanakan di wilayah komunitas Kota Pontianak pada periode Oktober-Desember 2013.

\section{Instrumen Penelitian}

Uji validitas yang dilakukan pada seluruh instrument penelitian ini adalah menggunakan face validity, content validity. Setiap pertanyaan telah dilakukan uji validitas dengan face validity, content validity, dan correlated correction yang menunjukkan instrument ini valid. Uji 
coba instrumen dilakukan kepada 15 orang responden yang berbeda.

\section{HASIL}

Berdasarkan

karakteristik

demografi pada 35 responden ibu ditemukan sebagian besar usia ibu $85.7 \%$ ( 30 orang) berusia antara $20-30$ tahun. Status pendidikan ibu ditemukan bahwa sebagian besar berpendidikan tinggi yaitu $74.3 \%$ dan hanya 1 orang $(2.9 \%)$ yang berpendidikan rendah yaitu tidak tamat Sekolah Dasar. Status pekerjaan ibu menunjukkan bahwa sebagian besar adalah ibu yang bekerja yaitu $60 \%$ (21 orang).

Pada karakteristik jumlah anak $68.6 \%$ (24 orang) menyatakan baru memiliki satu anak dan sisanya adalah ibu dengan anak lebih dari satu. Pada jumlah pendapatan didapatkan data bahwa sebagian besar keluarga (94 \%) berpendapatan di atas rata-rata UMR Provinsi Kalimantan Barat. Berdasarkan karakteristik anak, ditemukan bahwa sebagian besar anak dari responden adalah berusia lebih dari 6 bulan yaitu $71.4 \%$ (25 orang) dengan usia kelahiran cukup bulan (97.1 \%) dan berat lahir dalam rentang normal $(94.3 \%)$.

Sebagian besar ibu memiliki paparan tinggi atau melebihi paparan ratarata pada penggunaan media sosial. Berdasarkan analisis frekuensi, dari 35 responden ibu sebanyak $62,9 \%$ responden memiliki paparan media sosial yang tinggi dan sebanyak $37.1 \%$ responden ibu memiliki paparan media sosial yang rendah

Sebagian besar ibu memiliki tingkat pengetahuan yang melebihi ratarata terhadap ASI ekslusif atau pengetahuan menyusui efektif. Berdasarkan analisis frekuensi, dari 35 responden ibu sebanyak $62,9 \%$ responden memiliki pengetahuan yang tinggi dan sebanyak $37.1 \%$ responden ibu memiliki pengetahuan yang relatif kurang. 
Rata-rata sebagian besar ibu telah memberikan ASI ekslusif pada anaknya saat usia 0-6 bulan. Berdasarkan analisis frekuensi, dari 35 responden ibu sebanyak $60 \%$ responden telah memberikan ASI ekslusif pada anaknya saat usia 0-6 bulan dan sebanyak $40 \%$ tidak melaksanakan pemberian ASI ekslusif.

Analisis data bivariat dilakukan dengan uji statistik menggunakan uji Spearman dikarenakan distribusi data tidak normal. Hasil dari uji Spearman didapatkan hasil 0,437 yang berarti bahwa tidak ada pengaruh dan korelasi antara pengetahuan ibu terhadap pemberian ASI namun ada pengaruh dan korelasi antara paparan media sosial terhadap perilaku menyusui ASI ekslusif ibu dengan nilai $\mathrm{p}$ $=0,009$.

\section{PEMBAHASAN}

Jika paparan media sosial di media elektronik tidak memiliki pengaruh atau korelasi terhadap pengetahuan ibu untuk menyusui ASI ekslusif hal ini dapat saja disebabkan oleh adanya informasi dan iklan dari pemerintah yang gencar menggalakkan ASI ekslusif sejak sebelum ASI ekslusif menjadi topik tren di media sosial sehingga para ibu sudah sering mendengar tentang ASI ekslusif selain dari media sosial walaupun tidak dapat dipastikan pengetahuan itu berkorelasi terhadap perubahan sikap dan keputusan untuk menyusui ekslusif karena saat ini iklan susu formula juga semakin banyak dan gencar dengan unggulan pada perbaikan imunitas dan fungsi otak anak.

Tingkat pendidikan ibu yang berbeda juga dapat mempengaruhi cara pandang dan pemahaman terhadap informasi yang didapat mengenai ASI ekslusif ${ }^{1}$. Walaupun pada penelitian ini sebagian besar responden (74\%) adalah ibu dengan latar belakang pendidikan tinggi namun banyak faktor yang mempengaruhi pengetahuan ibu selain tingkat pendidikan, misalnya paparan informasi, akses informasi, kemauan mencari informasi. 
Melalui paparan media sosial, seorang ibu dapat terpengaruh secara berpikir dan sikap untuk mengambil keputusan tentang menyusui secara ekslusif dan meningkatkan pemahaman terhdap ASI. Media sosial dapat mempengaruhi keputusan ibu dalam inisiasi menyusui, intensitas menyusui, dan durasi dalam menyusui.

Saat ini paparan iklan susu formula melalui media sosial merupakan tantangan bagi penyampaian informasi tentang ASI ekslusif. Iklan susu formula dihubungkan dengan kejadian memendeknya masa menyusui ekslusif dan informasi tentang susu formula tersebut berkaitan dengan berkurangnya intensitas menyusui dan inisiasi spontan dalam menyusui ${ }^{8}$. Penelitian yang dilakukan oleh Zhang menyimpulkan bahwa adanya paparan iklan susu formula pada mesia sosial sejak awal kehamilan ibu hingga saat persalinan sangat berpengaruh pada keputusan ibu apakah memberikan ASI ekslusif atau susu formula sesaat setelah bayi lahir, justru para ibu lebih cepat memutuskan untuk memberikan susu formula di awal kelahiran bayi karena paparan iklan tersebut ${ }^{8}$.

$$
\text { Berdasarkan penelitian yang }
$$
dilakukan oleh Matias, dkk tentang faktor yang mempengaruhi pemberian ASI ekslusif pada ibu di Peru, ditemukan bahwa faktor lain non media juga mempengaruhi inisiasi dan durasi dalam memberikan ASI ekslusif sepeti tingkat pendidikan ibu, status IMT ibu, nyeri pada putting yang muncul mulai pada hari ke-4, nyeri pada payudara yang muncul mulai pada hari ke-2, pekerjaan ibu, dan penggunaan DMPA (depot medroxyprogesterone acetate) pada bulan ke-3 atau bulan ke-6 pasca melahirkan. Beberapa faktor tersebut sangat berpengaruh pada perilaku dan kontinuitas ibu dalam menjaga ASI ekslusif untuk bayinya 9 .

Para Ibu di Indonesia khususnya di Kota Pontianak menyatakan bahwa sebanyak $60 \%$ responden memberikan 
ASI ekslusif pada bayinya hingga selesai.

Para ibu menyatakan media sosial mempengaruhi ibu untuk mengambil keputusan menyusui ekslusif pada usia bayi 0-6 bulan; mempengaruhi ibu untuk tetap menyusui bayinya hingga usia bayi lebih dari 6 bulan; membantu ibu dalam memperoleh tips-tips tentang pemberian ASI ekslusif; mendatangkan dukungan dari suami/ pasangan serta komunitas sesama ibu menyusui; dan membantu ibu dalam menghadapi tantangan dalam menyusui seperti bekerja, produksi menurun, sakit. Jika realitas ini dibawa ke wilayah pedesaan maka belum tentu dapat disamakan karena biasanya di pedesaan perilaku menyusui ekslusif mungkin disebabkan oleh faktor ekonomi dan budaya tradisional

\section{KESIMPULAN}

Media sosial mempengaruhi persepsi individu sehingga berdampak pada perilaku menyusui yang efektif oleh ibu kepada bayinya. Paparan informasi dari media sosial sebagai bentuk dukungan tidak langsung kepada ibu berpengaruh pada perilaku ibu dalam memberikan ASI ekslusif

\section{DAFTAR PUSTAKA}

1. Depkes RI. Riset Kesehatan Dasar 2010. 2010. diambil pada tanggal 24 Juni 2013 dari www.litbang.depkes.go.id/...riskesdas 2010 /Laporan_riskesdas_2010.pdf

2. Depkes RI. Strategi Nasional PP-ASI. 2008. Diambil pada tanggal 24 Juni 2013 melalui www.gizi.depkes.go.id/kebijakangizi/.../stranas\%20final.doc

3. Morisset, Aubert-Jacquin C, Soulaines P., Moneret-Vautrin DA., Dupont C. A nonhydrolyzed, fermented milk formula reduces digestive and respiratory events in infants at high risk of allergy. European Journal of Clinical Nutrition. 2011; 65, 175-83

4. Chandra, RK. Food hypersensitivity and allergic diseases. European Journal of Clinical Nutrition; 2002, 56, Suppl 3, S54-6. Memorial University of Newfoundland, Janeway Child Health Centre, St John's, Newfoundland, Canada

5. UNICEF. Breastfeeding Saves More Lives Than Any Other Preventive Intervention. $2014 . \quad$ http:// unicef.org/nutrition/index_24824.html

6. Evans, D. Social Media Marketing An Hour A Day, Wiley Publishing, Inc : Canada. 2008

7. Kelana, DK. Metodologi Penelitian Keperawatan: Panduan Melaksanakan dan Menerapkan Hasil Penelitian. Jakarta: Trans InfoMedia. 2011

8. Zhang, Y.; Carlton, E.; Fein, S. The Association of Prenatal Media Marketing Exposure Recall with Breastfeeding Intentions, Initiation, and Duration. J Hum Lact 2013; 29, 500-9.

9. Matias SL., Nommsen-Rivers LA., Dewey KG. (2012). Determinants of Exclusive Breastfeeding in a Cohort of Primiparous Periurban Peruvian Mothers. J Hum Lact 2012; 28: 45. 